logos_i_ethos_2017_(45)_numer specjalny, s. 163-176

DOI: http://dx.doi.org/10.15633/lie.2344

\author{
Barbara Żmuda-Frydrychowska \\ Uniwersytet Papieski Jana Pawła II w Krakowie
}

\title{
Umiar i rozsądek lekarstwem na przesadną konsumpcję
}

Celem niniejszego artykułu jest próba zastosowania filozofii personalistycznej Adama Rodzińskiego jako swoistego remedium na problemy konsumpcyjnego sposobu życia. Ponieważ współczesny konsument jawi się jako egoista szukający jedynie własnej rozrywki, warto przyjrzeć się bliżej dwóm wartościom, które wydają się bardzo dobrze obrazować tę tendencję w życiu homo consumens,

Barbara Żmuda-Frydrychowska, mgr, doktorantka w Katedrze Etyki Uniwersytetu Papieskiego Jana Pawła II w Krakowie. Absolwentka studiów magisterskich na Wydziale Filozoficznym UPJPII. Ważniejsze publikacje: Rationality as a Guarantee of Human Dignity, w: Racionálne - iracionálne, eds. P. Sucharek, O. Marchevsky, Prešov 2015; Pułapka szczęścia współczesnego człowieka, „Logos i Ethos” $2016 \mathrm{nr} 40$ (numer specjalny), s. 41-51. Zainteresowania naukowe: etyka personalistyczna, prawa człowieka, bioetyka, etyka biznesu, etyka zawodowa oraz etyka polityki. a są nimi wygoda i przygoda, pretendujące do rangi podstawowych wyznaczników życia. Konsument usilnie zabiega o wspomniane aktywności, aby w jego życiu nie pojawiła się destrukcyjna nuda. Taki model egzystencji, w którym konsumpcja odgrywa kluczową rolę, jest z jasnych powodów krytykowany przez współczesnych personalistów. Warto więc zastanowić się nad pytaniem, czy aby żyć zgodnie z zasadami filozofii chrześcijańskiej, powinniśmy wyrzec się wygodnego sposobu życia oraz emocjonujących przygód, czy może jednak pojawia się jeszcze inna alternatywa dla etycznego konsumenta.

\section{Charakterystyka wartości w świecie konsumpcji}

Wiek XX przyniósł nam wiele zmian zarówno w świadomości ludzkiej, jak i stylach życia społecznego. Zmianie uległ model rodziny, sposób 
spędzania wolnego czasu oraz system wydawania pieniędzy. Pojęcie trwałości współcześnie zaczyna być pewnego rodzaju archaizmem, zarówno w odniesieniu do przedmiotów, jak i do stosunków międzyludzkich. Dawniej świat wydawał się człowiekowi bardziej realny i trwały, ponieważ przedmioty, które go otaczały, były czymś trwałym. Także w sferze społecznej ludzie żyli w sposób bardziej zależny od siebie - byli bardziej przywiązani do swojego otoczenia, zarówno materialnego, jak i społecznego. Dzisiaj sprzęty, jakie posiadamy, pełnią jedynie rolę otaczających nas gadżetów, które nieustannie zmieniamy i łatwo wyrzucamy do kosza. Człowiek nie przywiązuje się do rzeczy, traktuje je wyłącznie użytkowo, jedne mają mu zapewnić rozrywkę, inne służą do pracy, a pozostałe pomagają w domu. Życie ludzkie stało się o wiele prostsze i wygodniejsze dzięki coraz to nowym gadżetom. Jednak przez to zmienia się również nasz stosunek do tego, co nas otacza - zaczynamy ludzi traktować podobnie jak rzeczy, coraz łatwiej przychodzi nam „wymienianie” otaczających nas osób, związki międzyludzkie są coraz mniej trwałe. Nie jesteśmy już tacy chętni do angażowania się w bliższe relacje z innymi. Skutkiem tych przemian, oprócz wygody wynikającej z posiadania ogromnej liczby gadżetów „ułatwiających” nasze funkcjonowanie, jest rosnąca samotność międzyludzka. Każdy żyje sam dla siebie, nie zwracając uwagi na innych. Jesteśmy wygodni, a im mniejsza jest nasza odpowiedzialność za otaczający nas świat i ludzi, tym bardziej komfortowo się czujemy. Przesadny konsumpcjonizm prowadzi więc do egoizmu i egocentryzmu, które w konsekwencji powodują wyalienowanie jednostki - stajemy się samotnikami skoncentrowanymi wyłącznie na własnej osobie ${ }^{1}$.

Konsumpcyjne jednostki nastawione są głównie na kupowanie - kupujemy coraz więcej, wydając przy tym coraz większe sumy pieniędzy na przedmioty i usługi, które wydają nam się niezbędne, oraz na takie, które są chwilowym kaprysem albo okazją do popisania się przed sąsiadami. Często gromadzimy gadżety na pokaz. Dostępność różnorodnych i odpowiednio rozreklamowanych produktów sprawia, że ulegamy marketingowi i otwieramy nasze portfele coraz szerzej. Rozwój reklamy i technik

1 Por. Z. Bauman, Dwa szkice o moralności ponowoczesnej, Warszawa 1994. 
marketingowych powoduje, że koło kupowania się zamyka, stąd też nie sposób dostrzec końca. Czerpiemy satysfakcję z kupowania coraz to nowych rozmaitych przedmiotów, nawet jeśli skorzystamy z nich tylko raz albo nawet nie skorzystamy wcale ${ }^{2}$.

Kolejnym ważnym elementem świata ponowoczesnego jest czas wolny, traktowany oczywiście jako czas konsumpcji, w którym człowiek zaspokaja swoje potrzeby. Przy nadmiernej konsumpcji dóbr i usług, ze sztucznie wywołanymi potrzebami, które nie prowadzą do poprawy jakości życia, pojawia się poważny problem równowagi w zaspokojeniu potrzeb. Bywa, że przy ich zaspokajaniu liczy się tylko posiadanie, pomnażanie i używanie dóbr z pominięciem innych wartości, i to bez względu na koszty ekologiczne, indywidualne czy społeczne ${ }^{3}$. Potrzeby związane z czasem wolnym konsumenci realizują w domu (np. oglądanie telewizji, odpoczynek, korzystanie z komputera, czytanie książki), w placówkach/instytucjach usługowych (np. kino, teatr, klub fitness, restauracja) oraz na łonie natury (np. las, park) ${ }^{4}$. W każdej z tych kilku rodzajów aktywności chodzi o to, by używać dóbr, dobrze się bawić i nie przejmować się innymi.

Na każdym kroku jednostki coraz bardziej oddalają się od siebie, funkcjonują w wielu przestrzeniach społecznych, które nierzadko się wykluczają. Dysponując wolnym czasem, chętniej spędzamy go pozamykani w domach niż we wspólnocie. Rozrywki, z których korzystano w gronie społecznym, z sąsiadami bądź podczas wspólnych miejskich festynów, zostały zastąpione interaktywnymi formami zabawy. Manuel Castells podkreśla, że istotnymi cechami nowego stylu życiu stały się właśnie homocentryczność i indywidualizm. Wolimy usiąść wygodnie przed ekranem telewizora czy monitora komputerowego, niż wyjść i spotkać się z bliskimi. Od sąsiadów odgradzamy się murami, instalujemy domofony,

2 Por. M. Wróbel, Konsumpcjonizm a etyczna konsumpcja jako alternatywne formy ksztaltowania społeczeństw, „Studies \& Proceedings of Polish Association for Knowledge Management” 51 (2011), s. 104nn.

${ }^{3}$ Por. M. Janoś-Kresło, Usługi społeczne a zrównoważony rozwój regionów, Warszawa 2008, s. 53.

4 Por. B. Kolny, Czas wolny w świetle zrównoważonego rozwoju, „Konsumpcja i Rozwój” 2014 nr 2 (7), s. 29. 
wybieramy strzeżone osiedla, by nikt niepożądany nie wkroczył w naszą prywatną przestrzeń ${ }^{5}$. Rodzice, dla świętego spokoju, wolą sprezentować dziecku komputer, który doskonale wypełni jego dzień, niż organizować mu czas wolny, wspólnie z nim. Dodatkowo przypisują tej metodzie cechy najbardziej optymalnej, niezagrażającej, a nawet edukacyjnej i stymulującej rozwój dziecka. Prawdą jednak jest, że rodzice nie tylko nie mają żadnej kontroli nad tym, czym zajmują się ich dzieci w tym czasie, ale i źle oceniają czas spędzony przez ich pociechy przed komputerem bądź telewizorem ${ }^{6}$. Niestety, rodzice wolą ignorować te niepokojące głosy, bowiem telewizja doskonale sprawdza się w roli niani, pozwalając im na wykonywanie pozostałych obowiązków domowych.

Jak wskazano powyżej, współczesny człowiek woli ignorować powstające problemy lub nawet udawać, że ich nie ma, ponieważ tak jest łatwiej. Jeżeli coś się popsuję, kupuję nowe; jeżeli ktoś przestaje mi odpowiadać, znajduję sobie kogoś, kto w danym momencie będzie do mnie pasował. Żyjemy w czasach, w których nie naprawia się zniszczonych rzeczy, a nawet relacji międzyludzkich - po prostu wymienia się je na nowe. Tak jest wygodniej, ciekawiej - ponieważ nieustannie otaczamy się czymś nowym. Żyjemy dynamicznie, nie lubimy monotonii, stąd też wygoda i przygoda plasują się tak wysoko na piramidzie wartości konsumpcjonizmu.

\section{Wygoda i przygoda oczami konsumpcjonisty}

Tego, jak ważna dla współczesnego społeczeństwa jest wygoda, raczej nie trzeba szczegółowo uzasadniać, ponieważ dążenie do komfortu każdy zna z własnego doświadczenia, a zwłaszcza z tych sytuacji, w których mocno kontrastowało ono z niewygodą. Jednak samo jej pojęcie okazuje się zakresowo dość rozległe, co wiąże się z pewnym zanalogizowaniem jego treści: np. gdy mówimy o wygodnych butach, wygodnym światopoglądzie

5 Por. M. Castells, Społeczeństwo sieci, Warszawa 2007, s. 375.

6 Por. C. Timoszczyk-Tomczak, Czas spędzony przed komputerem i telewizorem wświadomości dzieci oraz rodziców, w: (Kon)teksty kultury medialnej. Analizy i interpretacje, red. M. Sokołowski, t. 2, Olsztyn 2007, s. 239. 
czy wygodnym życiu. Takie przejawy wygody nie wydają się mieć rażąco pejoratywnego znaczenia, amerykańskie „take it easy” (nie rób z tego problemu, spróbuj podejść do tego czy owego jak najprościej) wydaje się zasługiwać na aprobatę. Jednak już przesadne zamiłowanie do wygód, które chyba najtrafniej można określić mianem wygodnictwa, słusznie wzbudza naszą niechęć. Profesor Rodziński z Katolickiego Uniwersytetu Lubelskiego, zastanawiając się nad tym problemem, podkreślał, że w kwestii wygody zawsze należy pamiętać o tym, co wszystkim powinno być wiadome, a chodzi tu prostą zasadę, że „wygodnie nie zawsze znaczy godnie" ". Stąd też warto - w oparciu o tę podstawę - rozważyć kwestię dążenia współczesnych ludzi do wygód i przygodności.

Z tego, co przedstawiono powyżej, wynika, że każdy z nas zabiega o jakąś formę wygody, a jednak, co ciekawe - pomijając pewne względy uboczne - często kwalifikujemy tę wartość raczej negatywnie. Powodem tego jest fakt, że z wygody rodzi się cała masa paradoksalnych „trudności z ułatwień", współcześni ludzie, jak powie Rodziński, popadają w ambaras z nadmiaru wygody: „Z architektonicznych klocków wieje monotonią i martwotą, nerwice emerytalne i świąteczne, kłopoty z układem krążenia nękają ludzi, którzy nade wszystko wolą wszędzie toczyć się na kółkach, zamiast przespacerować się do miasta na zakupy czy miejsca pracy. «Człowiek wygodny» - główny produkt tej cywilizacji, która na tak wielką skalę zastępuje naturę techniką - im bardziej gorączkowo szuka spokoju i wszelkiego rodzaju udogodnień, tym bardziej czuje się źle, im zaś gorzej się czuje, tym skwapliwiej ucieka przed trudem. Jest to groźny circulus o charakterze sprzężenia zwrotnego: błędne koło toczące się

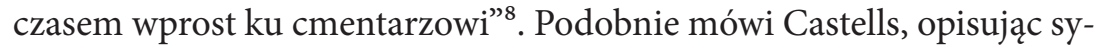
tuację, gdzie po całym dniu gonitwy za pieniądzem najchętniej szukamy wygodnego fotela i włączamy telewizor, który pozwala nam skutecznie odciąć się od trudów codzienności ${ }^{9}$. Medialne formy spędzania wolnego czasu stają się dominującą formą rozrywki. Bierne spędzanie czasu przed

\footnotetext{
7 A. Rodziński, Osoba i kultura, Warszawa 1985, s. 153.

8 A. Rodziński, Osoba i kultura, dz. cyt., s. 153n.

9 Por. M. Castells, Społeczeństwo sieci, dz. cyt., s. 340.
} 
odbiornikiem telewizyjnym czy ekranem komputera zajmuje nam nawet kilka godzin dziennie ${ }^{10}$.

Jednak nie jest tak, że wszyscy w stu procentach zadowolimy się taką bierną formą rozrywki, niektórzy w celu tak zwanego „zresetowania się" po pracy lub na urlopie, potrzebują pewnej dozy adrenaliny. Rynek konsumencki na to również jest przygotowany, proponując szeroki wachlarz ekstremalnych rozrywek. Młodzi ludzie niekiedy zaczynają zdawać sobie sprawę, że siedzenie w wygodnym fotelu, w komfortowo urządzonym i bezpiecznym domu w końcu okazuje się strasznie nudne, a tego już nie preferują. Stąd też zaczynają traktować swoją egzystencję jako jedną wielką, ryzykowną, a przez to i fascynującą grę; bo - jak powie Rodziński „o ile wygoda to pewien ukwalifikowany stosownie stan rzeczy, który nawet w ruchu jest przeżywany biernie, o tyle przygoda jest jakimś wydarzeniem: odnudzającym wydarzeniem, przeżyciem pełnym dynamiki, w trakcie którego człowiek sprawdza na co go stać, jakie w nim drzemią potencje, czasem ukryte, a warte - być może - rozbudzenia” ${ }^{11}$. Taki „człowiek przygody" pragnie nieustannych zmian, miłego wstrząsu, jaki te zmiany powodują. Współcześnie również wiele biur turystycznych specjalizuje się w organizacji „wczasów wielkiej przygody”, nietypowych pobytów w różnych zakątkach świata, dla ludzi, którzy podczas wakacji szukają czegoś więcej niż spokojnego relaksu. Podróże do egzotycznych krajów, w których możemy na własne oczy zobaczyć coś egzotycznego, są coraz tańsze. Dużą popularność zyskują dziś wycieczki, które prowadzą szlakami rdzennych mieszkańców danych regionów. Zamknięty kurort już nie jest tym, czego szukają turyści-konsumenci. Podczas wypoczynku chcą oni dodatkowo zakosztować czegoś egzotycznego, czegoś, co stanowi o oryginalności miejsca, które odwiedzają. Stąd też biura podróży dają swoim klientom takie możliwości, organizując pobyty w specjalnie przygotowanych kurortach, gdzie można zasmakować tradycji regionu.

10 Por. M. Szpunar, Czas wolny w dobie konsumpcjonizmu i powszechnej mediatyzacji, w: Homo creator czy homo ludens? Twórcy - internauci - podróżnicy, red. W. Muszyński, M. Sokołowski, Toruń 2008, s. 131.

11 A. Rodziński, Osoba i kultura, dz. cyt., s. 155. 
Mamy tutaj do czynienia z tak zwaną „inscenizowaną autentycznością”, o której pisze Dean MacCannel w swojej pracy Turysta, nowa teoria klasy próżniaczej. Książka podaje liczne przykłady na to, jaką popularnością wśród turystów cieszą się sztucznie zainscenizowane rytuały tubylcze ${ }^{12}$. MacCannell odnosi się tym samym do teorii sceny i kulisów życia publicznego Goffmana, w której wszystkie turystyczne atrakcje są inscenizowane na „etniczne” i dostosowywane do oczekiwań turystów. Nieświadomi tych zabiegów konsumenci, zachwyceni otaczającymi ich przedmiotami, korzystają z licznych atrakcji i chętniej wydają na nie swoje pieniądze ${ }^{13}$.

Aleksandra Perczyńska w jednym ze swoich artykułów zwraca uwagę, że współcześnie pojawiają się konsumenci, którzy świadomie decydują się na rozrywkę w sztucznie zainscenizowanych miejscach. Przykładami takich miejsc są różne parki tematyczne, w tym Disney World. Autorka nazywa takich ludzi „świadomymi konsumentami”, którzy żyją w rzeczywistości hiperkonsumpcji i zdają sobie sprawę, że rynki, marki i wizerunki walczą o ich uwagę: „Post-turysta wie, że ma wybór i oczekuje wysokiej jakości usług, wygody i przewidywalności. Sztuczność atrakcji turystycznych go nie zajmuje, a turystyka to dla niego jeszcze jeden rodzaj rozrywki. Nie oszukuje się, że istnieją jeszcze miejsca albo ludzie nie skażone zachodnią cywilizacją" ${ }^{\text {"14 }}$. Podobnie pisze Maxine Feifer w książce pt. Turystyka w historii..., nazywając wyżej opisanych turystów „post-turystami”, których zachwyca sztuczność i nieautentyczność takich miejsc ${ }^{15}$.

W taki właśnie sposób człowiek chroni się przed znudzeniem. Monotonia życia napawa niektóre jednostki ogromną niechęcią, w której nie widać sensu ani jakiejś korzystnej odmiany ducha. Rodziński, używając

12 Por. D. MacCannell, Turysta. Nowa teoria klasy próżniaczej, tłum. E. Klekot, A. Wieczorkiewicz, Warszawa 2005, s. 143-167.

13 Por. Goffman rozwija tę teorię w swojej książce: E. Goffman, Człowiek w teatrze życia codziennego, tłum. H. Śpiewak, P. Śpiewak, Warszawa 2000.

14 A. Perczyńska, Post-turysta na wakacjach, http://www.dwutygodnik.com/artykul/1339-post-turysta-na-wakacjach.html (20.06.2016).

15 Por. M. Feifer, Tourism in History: From Imperial Rome to the Present, New York 1996, s. $253-271$. 
doniosłych słów, tę gonitwę za coraz to nowszymi wrażeniami podsumowuje następująco: „,przygoda] ów potwór, co śpi na dnie, gdy niebo się chmurzy, pochłonął już wielu nawigatorów znużonych poszukiwaniem swojej Itaki czy Kolchidy, tej jakiejś krainy słonecznej i pełnej dobra wszelakiego, jaka prześwituje w marzeniu - zawsze daleko poza wszystkim tym, co na tej ziemi stanowić może źródło radosnego oczarowania i zachwytu" ${ }^{\prime 6}$. Wizja, należy przyznać, bardzo romantyczna, jednak jak wskazuje Rodziński, zarazem moralnie trochę podejrzana. Człowiek żyjący od przygody do przygody - jeżeli tylko tym żyje - niewiele różni się od leniwego wygodnisia. Obaj karmią się jedynie wartościami przeżyciowymi, napawają się chwilą bieżącą, żyją przeżywaniem. Różnica jest tylko taka, że myśl o wygodach opanowuje zwykle człowieka, któremu niedostaje energii, więc raczej w wieku zaawansowanym, zaś rządza przygód opanowuje tych, którzy dysponują energią życiową w nadmiarze.

Jak widzimy, i „człowiek wygodny”, i „człowiek przygodny” to ludzie we władaniu rządz, „wodzeni za nos” przez coś, od czego nie mogą się wyzwolić, dopóki nie znajdą wyjścia z tej sytuacji. Wszystkie ich przedsięwzięcia nie wypływają z centralnej wartości, jaką jest osoba, dlatego, że osobowa godność człowieka domaga się dyspozycyjności wobec każdego obowiązku, a nie tylko wobec wygodnych powinności albo fascynujących i ciekawych zadań. Rodziński powie wprost: „człowiek żyje spełnianiem obowiązków moralnych: żyje tym znacznie głębiej i istotniej niż samym przeżywaniem czegokolwiek. Obowiązki zaś te są często nudne i niewygodne równocześnie. Wtedy dopiero i przez to spełnia się człowiek i urzeczywistnia w sposób integralnie ludzki"17. Słowa te stanowią mocny argument w krytyce konsumpcjonistycznego modelu życia.

\section{Personalistyczne spojrzenie na konsumpcję}

Można by się zastanawiać, co w tym złego, że chcemy żyć w lepszych warunkach czy wyższym standardzie, że chcemy używać życia, skoro

16 A. Rodziński, Osoba i kultura, dz. cyt., s. 155n.

17 A. Rodziński, Osoba i kultura, dz. cyt., s. 156. 
mamy do tego tyle możliwości. Odpowiedź jest dość prosta: nic, ale pod warunkiem, że nie popadniemy w skrajności. Kiedy chęć posiadania stanie się naszym priorytetem, możemy popaść w stan, kiedy „mieć” stanie się dla nas ważniejsze niż „być”. Konsekwencją tego będzie postrzeganie innych wyłącznie poprzez pryzmat tego, co posiadają. Nasze człowieczeństwo, to, jacy jesteśmy, straci na znaczeniu. Nie będzie ważne, jakimi ludźmi jesteśmy, lecz jedynie to, co posiadamy. Hedonistyczny materializm prowadzi do zatracenia więzi międzyludzkich i wyobcowania jednostki w wymiarze społecznym. Może to doprowadzić do stanu, w którym ludzie nie będą potrzebować innych w swoim życiu, ponieważ wszystko zastąpią im gadżety, które nie będą wymagać od nich niczego, poza ich zakupieniem. W zamian za to będą oferować pomoc w niemal wszystkich czynnościach oraz zapewniać rozrywkę ${ }^{18}$.

U podstaw personalizmu stoi teza, że człowiek w swojej naturze i kulturze powinien starać się stale i na każdym kroku wykraczać poza i ponad to, co nazywamy przeżywaniem. „Człowiek wygodny” i „człowiek przygodny” to "ludzie przeżywania”, to w obu przypadkach człowiek niepełny i okaleczony. Rodziński powie, że podobnie kultury środowiskowe, owładnięte czy to kultem wygody, czy przygody są chore. U źródeł problemu takiego stylu życia tkwi błąd mentalny polegający na tym, że na miejsce naczelne, zastrzeżone dla wartości ponadprzeżyciowych, transcendentnych, wprowadza się wartości przeżywania jako miarodajne w sposób absolutny, którym wobec tego zawsze przyznaje się pierwszeństwo. Cechą naszej cywilizacji technicznej jest to, że produkuje ona nie tylko zbyt wiele rzeczy zbytecznych, ale też wiele niepotrzebnych potrzeb, aby móc reklamować środki ich zaspokojenia i sprzedawać je z zyskiem ${ }^{19}$.

Gdzie zatem szukać rozwiązania? Wydawać by się mogło, że poszczególne formacje kulturowe - podobnie jak jednostki - które zbyt mocno zostały zdominowane kultem wygody czy przygody, może uratować jakieś znalezienie środka pomiędzy tymi dwoma ekstremami. Jednostronność,

18 Por. F. Bylok, Meandry konsumpcji we współczesnym społeczeństwie: konsumpcjonizm versus dekonsumpcja, „Annales. Etyka w życiu gospodarczym” 19 (2016) nr 1, s. 58-63.

19 Por. A. Rodziński, Osoba i kultura, dz. cyt., s. 157. 
jak wiemy z licznych doświadczeń - własnych i cudzych - z reguły jest szkodliwa. Jednak tu pojawia się problem, ponieważ wygoda i przygoda nie muszą koniecznie leżeć na dwu przeciwległych biegunach, z których w ramach pewnej resocjalizacji wybieralibyśmy sobie jakieś działanie pośrednie. W wielu przypadkach umiłowanie ryzyka i niebezpieczeństwa stapia się w jeden życiowy nurt z pożądliwą uciechą, której dostarcza łatwizna. Tak dzieje się przecież prawie codziennie w milionach domów, w których przed ekranem zasiada umasowiony homo spektator, aby - zapewne z jakąś smaczną przekąską - oglądać „dantejskie sceny” czy mrożące krew w żyłach epizody z tragicznego nieraz i wstrząsającego życia innych ludzi. Okazuje się, że chociaż cudza wygoda do konsumpcji raczej się nie nadaje, to cudze przygody „odnudzają” nas niekiedy tak dobrze jak własne. Z tego powodu poszukiwanie czegoś pośredniego pomiędzy skrajnym wygodnictwem a przygodą w praktyce musi zawodzić ${ }^{20}$.

$\mathrm{W}$ takim razie, jakie stanowisko wobec tego problemu zajmują personaliści? Z pewnością nie nakazują nam zupełnie zrezygnować z wartości, jakimi są wygoda i przygoda, niemniej jednak klasyfikują je jako wartości czysto doznaniowe, które w pewnych względach nadają się do tego, aby je przeżywać na bieżąco, ale nie nadają się do tego, aby nimi głównie bądź wyłącznie - żyć. Jak powie Rodziński, gdyby takie sytuacje miały miejsce, nie byłoby to życie w pełni ludzkie, na miarę osobowej godności człowieka ${ }^{21}$. Otóż, skoro nic, co ludzkie nie powinno nam być obce - jak głosi podstawowa zasada humanizmu - warto podkreślić, że w chrześcijańskiej koncepcji kultury nie chodzi na pewno ani o bezpardonowe zwalczanie wszelkich wygód, ani o to, żeby lękać się ewentualnej przygody, choćby i ryzykownej, gdy nam się przydarza. Rodziński powie, że rozwiązanie problemu leży w „sublimacji obu tych tendencji” ku wygodzie i przygodzie. Filozof tłumaczy to w następujący sposób: "chodzi o to, aby ani w próżniaczym wygodnictwie, ani w gorączkowym łowieniu przygód nie pogrążało się ludzkie serce i ludzkie życie. Nie wolno go puszczać samopas, gdzie wygoda i przygoda przedstawiają

20 Por. A. Rodziński, Osoba i kultura, dz. cyt., s. 157n.

21 Por. A. Rodziński, Osoba i kultura, dz. cyt., s. 157. 
się jako dwie - może na pozór tylko radykalnie rozbieżne drogi ucieczki od przykrych obowiązków"22. Stąd też wartości te, jakkolwiek mogą być i bywają pożądanym współczynnikiem stylu i jakości życia - to zwłaszcza gdy chodzi o życie chrześcijańskie - nie powinny wyznaczać zasadniczej jego dominanty. Rodziński podkreśla, że tylko podniesienie obu tych ogólnożyciowych orientacji na wyższą orbitę i w szersze aksjologiczne perspektywy życia duchowego może dostatecznie zabezpieczyć człowie$\mathrm{ka}$ - jego naturę i kulturę - przed pogrążeniem się we własnej pustce ${ }^{23}$.

Człowiek dojrzały wewnętrznie - homo maturus - pragnie nie tylko wygody i przygody, ale też intymności, swojskości, solidarności, wierności, akceptacji, szczerości i porozumienia, a także wielu innych wartości budujących rację, dla której warto żyć ${ }^{24}$. Nie możemy zapominać o naczelnej zasadzie, według której człowiek jest istotą społeczną i tylko wśród innych ludzi może żyć, prawidłowo funkcjonować i rozwijać się. W dzisiejszym ergonomicznym świecie, pełnym nowinek technicznych możemy korzystać z rozmaitych gadżetów, które sprawiają, że coraz rzadziej potrzebujemy pomocy ze strony innych ludzi. Skrajnie konsumpcjonistyczny styl życia destrukcyjnie wpływa na człowieka i jego relacje ze społeczeństwem. Stąd też uzasadnione jest konsumowanie z rozsądkiem i podejmowanie decyzji godnych inteligentnego człowieka XXI wieku.

\section{Podsumowanie}

Problem wygody i przygody jest jedynie jednym z wielu elementów, wokół których oscyluje tak zwana kultura konsumpcyjna. Krytycy ponowoczesności dostrzegają znacznie więcej podobnych problemów, które w analogiczny sposób wpływają na kondycję współczesnych jednostek. Rodziński sposób wyjścia ze skrajnego konsumpcjonizmu widzi w „prawdziwej humanizacji świata ludzkiego" ${ }^{25}$, która polega na jego repersona-

22 A. Rodziński, Osoba i kultura, dz. cyt., s. 159.

23 Por. A. Rodziński, Osoba i kultura, dz. cyt., s. 159.

24 Por. A. Rodziński, Osoba i kultura, dz. cyt., s. 159.

25 Określenie Adama Rodzińskiego, zob. A. Rodziński, Osoba i kultura, dz. cyt., s. 159 (przypis). 
lizacji, to znaczy zamiast urzeczowiać osoby, należy rzeczom przywracać pełny, duchowy, osobowy sens: człowiek zamiast na doznaniach przeżyciowych powinien skupić się na wartościach ponadprzeżyciowych, czyli „takich, którymi można duchowo żyć, niekoniecznie przeżywając je emocjonalnie; są one ważniejsze dla ludzkiej natury i kultury, one też mogą zapewnić człowiekowi autentyczną, trwałą, wewnętrzną integrację, a w konsekwencji poczucie sensu indywidualnego i zbiorowego życia pełnego dramatycznych alternatyw" ${ }^{\prime 2}$. Po wskazaniu zagrożeń wynikających $\mathrm{z}$ realiów współczesności i zestawiając je z ideami personalistycznymi, widzimy istotne niebezpieczeństwo, ponieważ zdajemy sobie sprawę, że nie jesteśmy w stanie powstrzymać rozpędu technologii, gospodarki wolnorynkowej i innych praw rządzących światem Zachodu. Jednak jeśli uda nam się nakierować myśli na wartości duchowe jako nadrzędne, przestrzegając przed nadmiernym czy nieograniczonym konsumpcjonizmem, to według personalistów będziemy w stanie funkcjonować w nowej rzeczywistości, nie tracąc przy tym swojego człowieczeństwa. Zadanie współczesnego człowieka polega na zmierzeniu się nadmiernym konsumpcjonizmem i zdystansowaniu się do sztucznych potrzeb w celu odnalezienia własnej tożsamości jako osoby ludzkiej ${ }^{27}$.

\section{Bibliografia}

Bauman Z., Dwa szkice o moralności ponowoczesnej, Warszawa 1994.

Bylok F., Meandry konsumpcji we współczesnym społeczeństwie: konsumpcjonizm versus dekonsumpcja, „Annales. Etyka w życiu gospodarczym” 19 (2016) nr 1, s. 55-69.

Castells M., Społeczeństwo sieci, Warszawa 2007.

Feifer M., Tourism in History: From Imperial Rome to the Present, New York 1996.

Goffman E., Człowiek w teatrze życia codziennego, tłum. H. Śpiewak, P. Śpiewak, Warszawa 2000.

26 A. Rodziński, Osoba i kultura, dz. cyt., s. 159n.

27 Por. K. Pasikowski, Pokusa konsumpcjonizmu w świetle personalizmu pedagogicznego, „Rozprawy Społeczne" 9 (2015) nr 4, s. 70. 
Janoś-Kresło M., Usługi społeczne a zrównoważony rozwój regionów, Warszawa 2008.

Kolny B., Czas wolny w świetle zrównoważonego rozwoju, „Konsumpcja i Rozwój” 2014 nr 2 (7), s. 28-38.

MacCannell D., Turysta. Nowa teoria klasy próżniaczej, tłum. E. Klekot, A. Wieczorkiewicz, Warszawa 2005.

Pasikowski K., Pokusa konsumpcjonizmu w świetle personalizmu pedagogicznego, „Rozprawy Społeczne” 9 (2015) nr 4, s. 64-70.

Perczyńska A., Post-turysta na wakacjach, http://www.dwutygodnik.com/artykul/1339post-turysta-na-wakacjach.html (20.06.2016).

Rodziński A., Osoba i kultura, Warszawa 1985.

Szpunar M., Czas wolny w dobie konsumpcjonizmu i powszechnej mediatyzacji, w: Homo creator czy homo ludens? Twórcy - internauci - podróżnicy, red. W. Muszyński, M. Sokołowski, Toruń 2008, s. 131-140.

Timoszczyk-Tomczak C., Czas spędzony przed komputerem i telewizorem w świadomości dzieci oraz rodziców, w: (Kon)teksty kultury medialnej. Analizy i interpretacje, red. M. Sokołowski, t. 2, Olsztyn 2007.

Wróbel M., Konsumpcjonizm a etyczna konsumpcja jako alternatywne formy kształtowania społeczeństw, „Studies \& Proceedings of Polish Association for Knowledge Management" 51 (2011), s. 103-116.

\section{Abstrakt}

\section{Umiar i rozsądek lekarstwem na przesadną konsumpcję}

Artykuł stanowi próbę zastosowania myśli personalistycznej Adama Rodzińskiego w odniesieniu do problemów, jakie stawia przed nami współczesny model konsumpcyjnego życia. W pierwszej kolejności przedstawione zostają zagrożenia wynikające z niewiarygodnie szybkiego postępu technologicznego oraz zmiany mentalności współczesnych jednostek. Następne wymienione sytuacje zostają skontrastowane z nakazami etyki personalistycznej w celu odnalezienia w nich sposobów wyjścia z kryzysu, który przyniosła tak zwana „rozbuchana konsumpcja”. Celem artykułu jest próba wykazania, że personalistycznym lekarstwem na przesadną konsumpcję wcale nie jest wyrzeczenie się jej, lecz rozsądne i umiarkowane podejście do konsumowania. 


\section{Słowa klucze}

Adam Rodziński, personalizm, konsumpcjonizm, wartości ponowoczesne, wygoda, przygoda

\section{Abstract}

\section{Moderation and Reason as a Remedy for Excessive Consumption}

The article is an attempt to use the personalist thought of Adam Rodziński on the problems posed by the contemporary model of consumerism. In the first part, the author presents the risks resulting from incredibly rapid technological progress and changes in the mentality of modern people. Then, these situations are contrasted with the dictates of personalistic ethics in order to find ways out of the crisis, which brought the so-called "overactive consumption". The article attempts to show that the personalist cure for excessive consumption, it is not renunciation of it, but sensible and moderate approach to consumption.

\section{Keywords}

Adam Rodziński, personalism, consumerism, postmodern values, comfort, adventure 